\title{
Rak nerkowokomórkowy — wyniki leczenia i skutki ekonomiczne wobec refundacyjnych możliwości w Polsce
}

\author{
Rafał Zyśk , Barbara Wójcik-Klikiewicz²
}

W związku z restrykcyjnymi procedurami refundacyjnymi dotyczącymi finansowania wysokokosztowych terapii onkologicznych, które nie zostały jeszcze ocenione przez Agencję Oceny Technologii Medycznych, świadczeniodawcy są zobligowani do wnioskowania do właściwego dyrektora oddziału wojewódzkiego Narodowego Fundusz Zdrowia o zgodę na finansowanie leczenia w trybie niestandardowym. Podstawowe dane sprawozdawane płatnikowi w systemie informatycznym, uzupełnione informacjami z Centralnego Wykazu Ubezpieczonych i dotyczące zgonów, pozwalają na określenie efektów tych terapii wyrażonych w postaci średnich wartości wskaźników przeżycia. W świetle powszechnej wiedzy środowiska klinicznego odnośnie częstych różnic pomiędzy efektywnością eksperymentalną leku (efficacy) uzyskaną w warunkach próby klinicznej i skutecznością w klinicznej praktyce (effectiveness) uzyskiwaną w warunkach codziennej praktyki klinicznej, w ramach niniejszej pracy dokonano wstępnej analizy danych w zakresie średniego czasu przeżycia całkowitego chorych leczonych z powodu raka nerkowokomórkowego z wykorzystaniem metod ukierunkowanych molekularnie, które były finansowane przez Narodowy Fundusz Zdrowia w trybie niestandardowym w okresie od stycznia 2009 roku do marca 2012 roku. Wyniki analizy wykazały, iż w przypadku większości terapii znaczący odsetek pacjentów leczonych w okresie poddanym analizie nadal żyje, co uniemożliwia obecnie ostateczną ocenę skuteczności w klinicznej praktyce. W celu wiarygodnej oceny czasu przeżycia całkowitego chorych włączonych do analizy niezbędne jest dalsze monitorowanie wyników leczenia oraz powtórzenie analizy po uzyskaniu nowych danych.

Analiza kosztów poniesionych w ostatnich latach przez Narodowy Fundusz Zdrowia na leki ukierunkowane molekularnie stosowane w leczeniu raka nerkowokomórkowego wykazała trend wzrostowy, który najprawdopodobniej zostanie utrzymany. Istotny wpływ na to będzie miał rozwój leczenia sekwencyjnego oraz wymierna efektywność kliniczna i kosztowa nowych terapii. W świetle powyższego uzasadnionym jest podjęcie prac nad centralnym rejestrem chorych na nowotwory nerki, umożliwiającym precyzyjne monitorowanie wyników leczenia oraz dostarczającym dokładnych danych klinicznych odnośnie wszystkich typów histologicznych raka nerkowokomórkowego.

\section{Renal-cell carcinoma - treatment results and economic effects in the face of reimbursement possibilities in Poland}

In connection with restrictive reimbursement procedures concerning funding high-cost oncological therapies which have not yet been evaluated by the Health Technology Assessment Agency, healthcare providers are obliged to apply to a competent director of the Regional Branch of the National Health Fund for consent to fund treatment in a non-standard mode. Basic data reported for a public payer in the computerized system was completed with information from the Central Register of Insured concerning death, and allowed us to define effects of these therapies, representing mean values of survival indicators. In the light of common knowledge of a clinical environment regarding frequent differences between experimental drug efficacy obtained in clinical trials and effectiveness in a clinical practice, obtained in conditions of everyday clinical practice, initial data analysis was made for the range of average time of overall survival of renal-cell carcinoma patients, using a molecular targeted therapies which were

${ }^{1}$ Kancelaria doradcza Health Economics Consulting w Warszawie

${ }^{2}$ Centrala Narodowego Funduszu Zdrowia, Departament Gospodarki Lekami w Warszawie 
funded by the National Health Fund in a non-standard mode from January 2009 to March 2012. The results of the analysis showed that in the case of most therapies a significant percentage of patients treated in the period of the analysis is still alive. To reliably evaluate the overall survival of renal-cell carcinoma patients included in this analysis it is necessary to monitor additional treatment results and repeat the analysis after receiving the new data.

Analysis of costs in recent years from the National Health Fund for molecular targeted drugs used in the treatment of renal-cell carcinoma showed an increasing trend, which is most likely to continue. Development of sequential treatment and measurable clinical effectiveness and cost-effectiveness of new therapies will have a significant influence on this issue. In the light of the above, it is reasonable to start work relating to the central register of renal-cell carcinoma patients which allows monitoring of treatment results precisely and can give accurate clinical data regarding all histological subtypes of renal-cell carcinoma.

NOWOTWORY Journal of Oncology 2013; 63, 3: 241-249

Słowa kluczowe: rak nerki, rak nerkowokomórkowy, chemioterapia niestandardowa, leczenie ukierunkowane molekularnie, skutki ekonomiczne, refundacja, efektywność kosztowa, koszty pośrednie, koszty leków, koszty choroby, rejestr pacjentów

Key words: kidney cancer, renal-cell carcinoma, non-standard chemotherapy, molecular targeted therapy, economic effects, medicine reimbursement, cost-effectiveness, indirect costs, drug costs, cost of illness, patient registry

\section{Wprowadzenie}

Wobec stosunkowo długotrwałej i silnie sformalizowanej procedury wdrażania nowych metod leczenia w programach lekowych (wcześniej - programy terapeutyczne) polscy onkolodzy stykali się wielokrotnie z koniecznością składania aplikacji do dyrektorów oddziałów wojewódzkich Narodowego Funduszu Zdrowia (NFZ) o niestandardowe finansowanie leczenia, które stanowią często międzynarodowy standard postępowania klinicznego. Wspomniany stan wynikał w dużej mierze z konieczności przedłożenia przez producenta wniosku refundacyjnego kierowanego do Ministra Zdrowia, jak również rozbudowanej dokumentacji klinicznej i farmakoekonomicznej. Dodatkową okolicznością o negatywnym znaczeniu był 180-dniowy okres przewidziany ustawowo dla urzędów na ocenę zasadności finansowania oraz ustalenia ceny dla nowego leku. W przypadku negatywnej opinii Agencji Oceny Technologii Medycznych (AOTM) finansowanie leczenia mogło być kontynuowane przez NFZ jedynie u chorych, którzy rozpoczęli leczenie przed wydaniem negatywnej opinii AOTM. Taka sytuacja dotyczyła m.in. bewacyzumabu, sorafenibu (do czasu wydania pozytywnej opinii), pazopanibu i temsyrolimusu. W lutym 2012 roku miało miejsce — pierwsze od września 2009 roku — rozszerzenie programu leczenia raka nerkowokomórkowego (RNK) o nowe leki (sorafenib i ewerolimus), co dla większości chorych poddawanych drugiej linii leczenia oznaczało brak konieczności wnioskowania o zgodę na sfinansowanie chemioterapii niestandardowej.

Na potrzeby obecnej publikacji dokonano analizy danych NFZ dotyczących przeżycia chorych leczonych w trybie chemioterapii niestandardowej oraz analizy wydatków poniesionych na świadczenia zdrowotne związane z leczeniem RNK.

\section{Prognozy epidemiologiczne w Polsce}

Analizy epidemiologiczne wskazują, że w przypadku utrzymania obecnego trendu zachorowalności w kolejnych latach, w 2030 roku na świecie zostanie odnotowanych około 22 milionów nowych zachorowań na nowotwory, co będzie stanowiło wzrost o około $75 \%$ w stosunku do roku 2008 [1]. Zgodnie z analizą Krajowego Rejestru Nowotworów (KRN) w 2009 roku odnotowano 138 tysięcy nowych zachorowań (wzrost o 2,1 tysiąca w stosunku do roku poprzedniego) na nowotwory złośliwe oraz 93 tysiące zgonów.

Zgodnie z danymi opublikowanymi przez Główny Urząd Statystyczny (GUS), w 1990 roku nowotwory złośliwe były przyczyną prawie 19\% zgonów, a w 2000 i 2010 roku stanowiły odpowiednio $23 \%$ i $24,5 \%$ wszystkich przyczyn. Oznacza to, że obecnie co czwarty zgon jest następstwem choroby nowotworowej (wśród mężczyzn - niespełna 26\%, wśród kobiet - prawie 23\%) [2].

Około 2-3\% wszystkich nowotworów złośliwych stanowi rak nerkowokomórkowy (RNK) [3]. Liczba zachorowań na nowotwory nerki u obu płci w Polsce charakteryzuje się znacznymi wahaniami, co utrudnia wiarygodną prognozę. Na podstawie trendów zachorowalności opublikowanych w 2011 roku przez KRN liczba przewidywanych zachorowań u mężczyzn i kobiet w 2012 roku wynosi odpowiednio około 3 i 2 tysiące. Wydaje się jednak, że obserwowany w latach 2009-2011 wzrost zapadalności (podobny u obu płci) może wynikać z innych przyczyn niż rzeczywisty przyrost liczby zachorowań (prawdopodobnie zwiększenie wykrywalności w związku z wprowadzeniem bardziej skutecznych metod obrazowej diagnostyki).

Liczba zgonów z powodu nowotworów nerki w polskiej populacji wśród mężczyzn i kobiet wykazuje tendencję rosnącą. Wzrost liczby zgonów może wynikać ze starzenia 


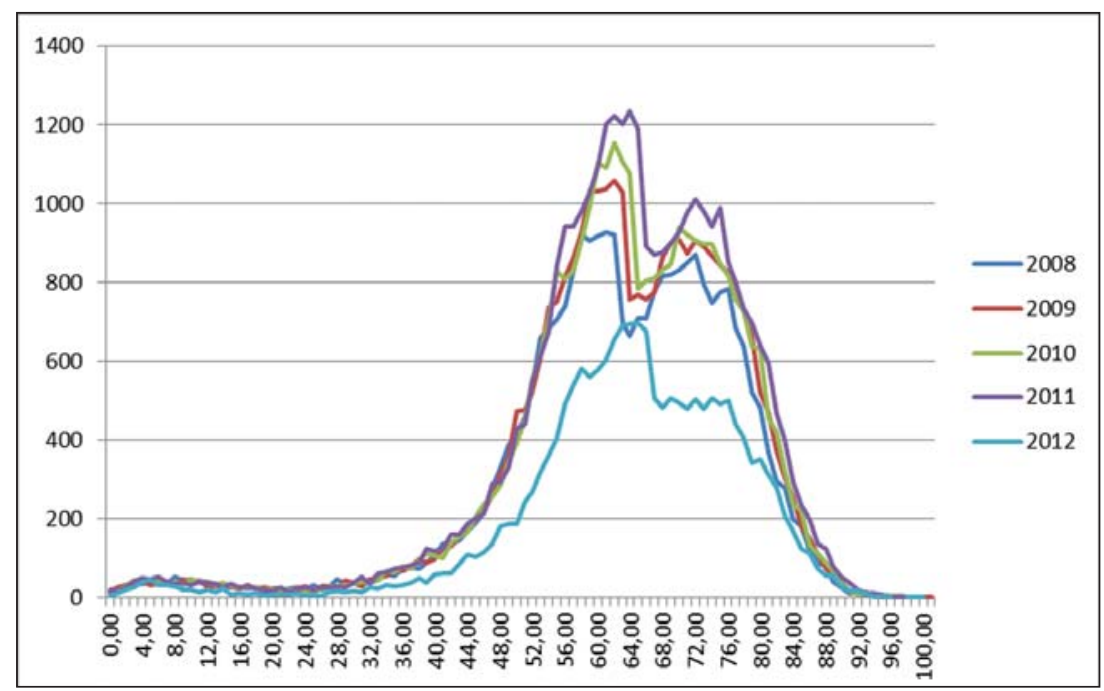

Rycina 1. Rozkład wieku chorych leczonych z powodu raka nerki (rozpoznanie główne) w okresie od stycznia 2008 r. do kwietnia 2012 r. Źródło: Centrala NFZ

się polskiego społeczeństwa i faktu, że 70\% zachorowań i zgonów u mężczyzn i 55\% zachorowań u kobiet $(80 \%$ zgonów) występuje po 60. roku życia. Przewidywana liczba zgonów w 2015 roku wyniesie ponad 1700 u mężczyzn i około 1000 u kobiet. Natomiast umieralność u obu płci wykazuje niewielką tendencję malejącą i w ciągu najbliższych lat powinna się utrzymać. Rosnąca liczba zgonów i malejące współczynniki umieralności wskazują, że - jak w raku płuca - za wzrost liczby zgonów odpowiada starzenie się populacji [4]. Szacuje się, że w 2025 roku większość zgonów będzie przypadać na najstarszą grupę wiekową (prawie 80\% u mężczyzn i około 90\% u kobiet) [5].

\section{Chorobowość i rozkład wieku chorych na nowotwory nerki w Polsce}

Dane sprawozdawcze NFZ dotyczące liczby chorych z rozpoznaniem RNK (unikalne numery PESEL/C-64), którzy skorzystali ze świadczeń finansowanych przez NFZ w 2011 roku, wskazują na wielkość populacji na poziomie około 33600 chorych.

Zgodnie z danymi KRN większość zachorowań na nowotwory nerki ma miejsce po 45. roku życia, z czego około połowa przypada na populację w średnim wieku (45-64lat), a druga część na populację po 65. roku życia. Prognozy KRN sugerują, że proporcje te ulegną prawdopodobnie zmianie i w 2025 roku w populacji mężczyzn około 35\% zachorowań będzie przypadać wśród osób w średnim wieku, a 60\% - w starszym wieku. U kobiet proporcje będą wynosić odpowiednio $20 \%$ i $70 \%$.

Dane NFZ wyraźnie wskazują, iż struktura wieku chorych leczonych z powodu RNK w latach 2008-2012 zmienia się w kierunku pacjentów starszych (ryc. 1). Wydaje się, że taki trend spowodowany jest przede wszystkim starzeniem się społeczeństwa. Najbardziej liczna grupa chorych mieści się w przedziale wiekowym między 55. a 80. rokiem życia. Z uwagi na prognozy demograficzne GUS, zapowiadające systematyczne starzenie się społeczeństwa polskiego do roku 2030 roku, należy przewidywać dalszy wzrost wykrywalności nowotworów związanych z wiekiem [6].

\section{Przeżycia chorych na nowotwory nerki leczonych w ramach procedury chemioterapii niestandardowej}

Na podstawie danych NFZ dotyczących czasu rozpoczęcia stosowania leku oraz dat zgonu pochodzących z Centralnego Wykazu Ubezpieczonych (CWU) określono przewidywane średnie okresy przeżycia chorych, którzy byli leczeni w ramach procedury chemioterapii niestandardowej i zmarli w okresie od 1 stycznia 2009 r. do 31 marca 2012 r. W związku z faktem, iż w przypadku bewacyzumabu, ewerolimusu i pazopanibu odsetek chorych nadal żyjących wynosi od $45 \%$ do $54 \%$, a w przypadku sunitynibu i sorafenibu - 36\% i 40\%, niemożliwe jest wnioskowanie odnośnie finalnego wyniku średniego czasu przeżycia całkowitego (overall survival - OS).

Jedynie w przypadku temsyrolimusu (wskazany u chorych o niekorzystnym rokowaniu według rokowniczej klasyfikacji MSKCC (Memorial Sloane Kettering Cancer Center) [7], z uwagi na fakt wystąpienia zgonu u 93\% leczonych, możliwe jest wstępne wnioskowanie odnośnie średniego OS uzyskanego w warunkach rzeczywistych. Średni OS na podstawie danych NFZ i ZUS w przypadku temsyrolimusu wynosi 10,6 miesiąca, co jest wynikiem zbliżonym do wartości z prospektywnego badania klinicznego (tab. I).

Należy podkreślić, iż powyższe dane nie odzwierciedlają mediany OS szacowanej w badaniach klinicznych metodą Kaplana-Meiera lub metodą aktuarialną, gdyż znaczący odsetek chorych leczonych w okresie przyjętym do analizy 
Tabela I. Leczenie finansowane w ramach procedury chemioterapii niestandardowej w okresie od stycznia 2009 r. do marca 2012 r.

\begin{tabular}{lccccc}
\hline Terapia & ICD10 & $\begin{array}{c}\text { Liczba pacjentów } \\
\text { włączonych do terapii }\end{array}$ & $\begin{array}{c}\text { Liczba pacjentów } \\
\text { zmarłych }\end{array}$ & $\begin{array}{c}\text { Średni czas terapii } \\
\text { Średni OS wg danych } \\
\text { NFZ (miesiące)* }\end{array}$ \\
\hline $\begin{array}{l}\text { Ewerolimus } \\
\text { Pazopanib }\end{array}$ & C64 & 647 & 324 & 4,7 & 7,0 \\
$\begin{array}{l}\text { (I ill linia) } \\
\text { Sorafenib }\end{array}$ & C64 & 181 & 83 & 6,6 & 9,0 \\
Temsyrolimus & C64 & 333 & 198 & 4,7 & 12,7 \\
Sunitynib & C64 & 93 & 87 & 6,0 & 10,6 \\
Bewacyzumab & C64 & 506 & 323 & 3,5 & 15,9 \\
\hline
\end{tabular}

Źródło: Centrala NFZ

*W związku z wysokim odsetkiem chorych żyjących dla większości analizowanych terapii wstępne dane dotyczące średniego czasu przeżycia całkowitego nie mogą być interpretowane jako skuteczność kliniczna leku

nadal żyje. Mając na względzie ten fakt, analiza powinna zostać powtórzona, gdy odsetek pacjentów zmarłych będzie pozwalał na wiarygodne wnioskowanie odnośnie średniej OS.

W najczęściej stosowanej w badaniach klinicznych metodzie estymacji OS według Kaplana-Meiera czas przeżycia oblicza się na podstawie współczynnika przeżycia, który z kolei kalkulowany jest przy użyciu warunkowych prawdopodobieństw.W metodzie tej interwały czasowe między kolejnymi pomiarami są zmienne, ponieważ analizy następują w momencie wystąpienia zdarzenia wynikowego (śmierć lub wycofanie chorego z badania) [8]. W tabeli I uproszczoną kalkulację czasu przeżycia oparto o średnią arytmetyczną dla OS ocenianego dla pacjentów zmarłych — OS definiowany był jako okres od rozpoczęcia terapii danym lekiem do daty zgonu (zgodnie z CWU).

Statystyczne metody oceny przewidywanego przeżycia stosowane w badaniach klinicznych posiadają swoje ograniczenia i uzupełniająca weryfikacja mediany czasu przeżycia wolnego od progresji choroby (progression-free survival - PFS) i OS poprzez prowadzenie precyzyjnego rejestru klinicznego mogłaby stanowić narzędzie wnoszące dodatkowe informacje oparte na danych rzeczywistych odnoszących się do polskiej populacji chorych. Niestety, dane NFZ, mimo iż obejmują niemal wszystkich chorych na nowotwory poddawanych leczeniu w Polsce, nie zawierają wielu istotnych informacji (np. charakterystyka występowania histologicznych typów nowotworów i struktura zaawansowania choroby w chwili rozpoczęcia leczenia, obecność biomarkerów, średni czas do progresji w warunkach rzeczywistych), które umożliwiałyby prowadzenie szczegółowych analiz. Ponadto gromadzenie danych na temat nowotworów w oparciu jedynie o kodyfikację ICD-10 wydaje się dzisiaj dalece niewystarczające. Brak odpowiednich danych skutkuje — między innymi — definiowaniem przez NFZ rozpoznania onkologicznego jedynie na podstawie kodu w klasyfikacji ICD-10, co implikuje restrykcyjne egzekwowanie przepisów dotyczących niefinansowania leczenia stosowanego w ramach procedury chemioterapii niestandardowej, finansowanego już w tak zdefiniowanym wskazaniu w programie lekowym lub wykazie substancji czynnych stosowanych w chemioterapii. W konsekwencji oznacza to, że chory z RNK o innym typie histologicznym niż określony w programie lekowym nie uzyska zgody na finnasowanie chemioterapii niestandardowej lekiem, który jest finansowany w programie. W przyszłości rozwiązaniem tego problemu mogłoby być uzupełnienie danych sprawozdawczych o kody w klasyfikacji ICD-O-3 (International Classification of Diseases for Oncology), umożliwiającej szczegółowe określenie topografii oraz postaci histologicznej nowotworu [9].

\section{Program lekowy w raku nerkowokomórkowym}

Aktualny kształt programu umożliwia kwalifikację chorych do pierwszej linii leczenia z udziałem sunitynibu, u których:

1. histologicznie potwierdzono rozpoznanie jasnokomórkowego raka nerki lub mieszanego raka nerkowokomórkowego z przeważającym (powyżej 60\% utkania) komponentem jasnokomórkowym oraz wykluczono obecność innych nowotworów złośliwych (z wyjątkiem przedinwazyjnego raka szyjki macicy oraz raka podstawnokomórkowego skóry);

2. nowotwór występuje w stadium zaawansowanym (pierwotne uogólnienie lub nawrót po pierwotnym leczeniu chirurgicznym) oraz udokumentowano obecność przerzutów narządowych, z wyjątkiem przerzutów do ośrodkowego układu nerwowym (OUN), stanowiących czynnik uniemożliwiający kwalifikowanie do udziału w programie;

3. nie prowadzono wcześniejszego leczenia farmakologicznego z powodu nowotworu nerki;

4. wykonano nefrektomię;

5. udokumentowano zmiany w badaniach KT lub MR;

6. stan sprawności oceniono na 80-100 wg skali Karnofsky'ego oraz stwierdzono korzystne lub pośrednie rokowanie według skali MSKCC;

7. wykluczono ciążę oraz karmienie piersią;

8. potwierdzono prawidłową czynność tarczycy i-w badaniach laboratoryjnych krwi - wykazano zadowalającą czynnościową wydolność narządową oraz wy- 


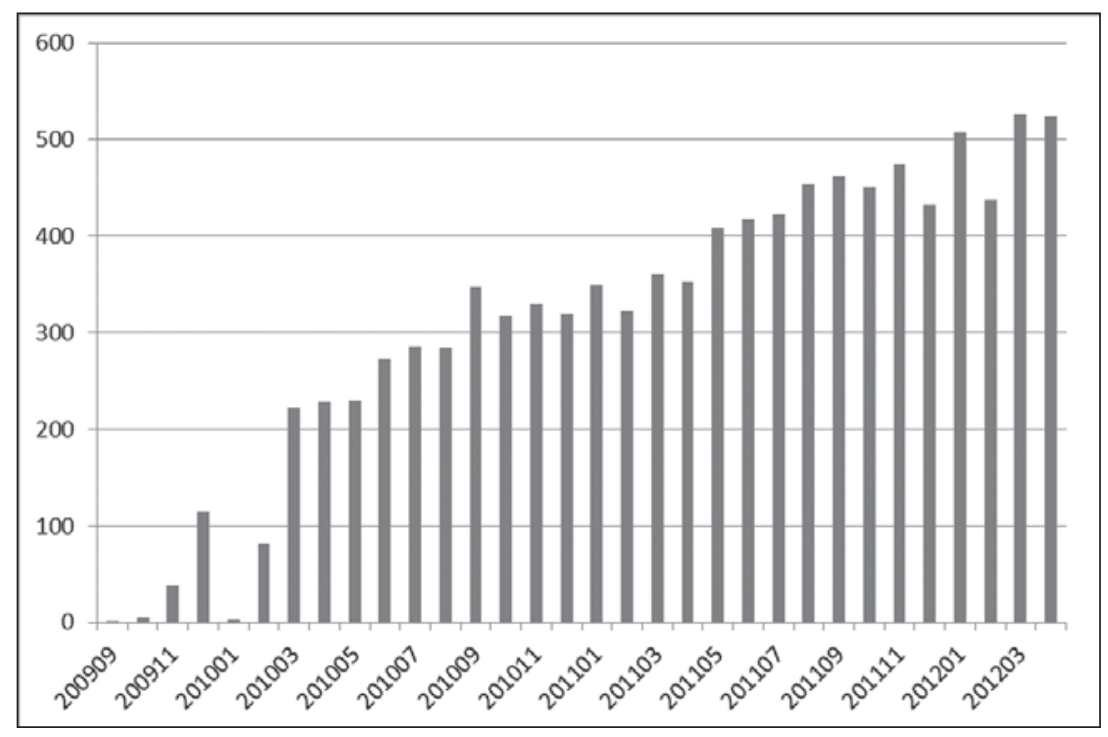

Rycina 2. Liczba chorych w programie leczenia raka nerki w okresie od września 2009 r. do kwietnia 2012 r. Źródło: Centrala NFZ

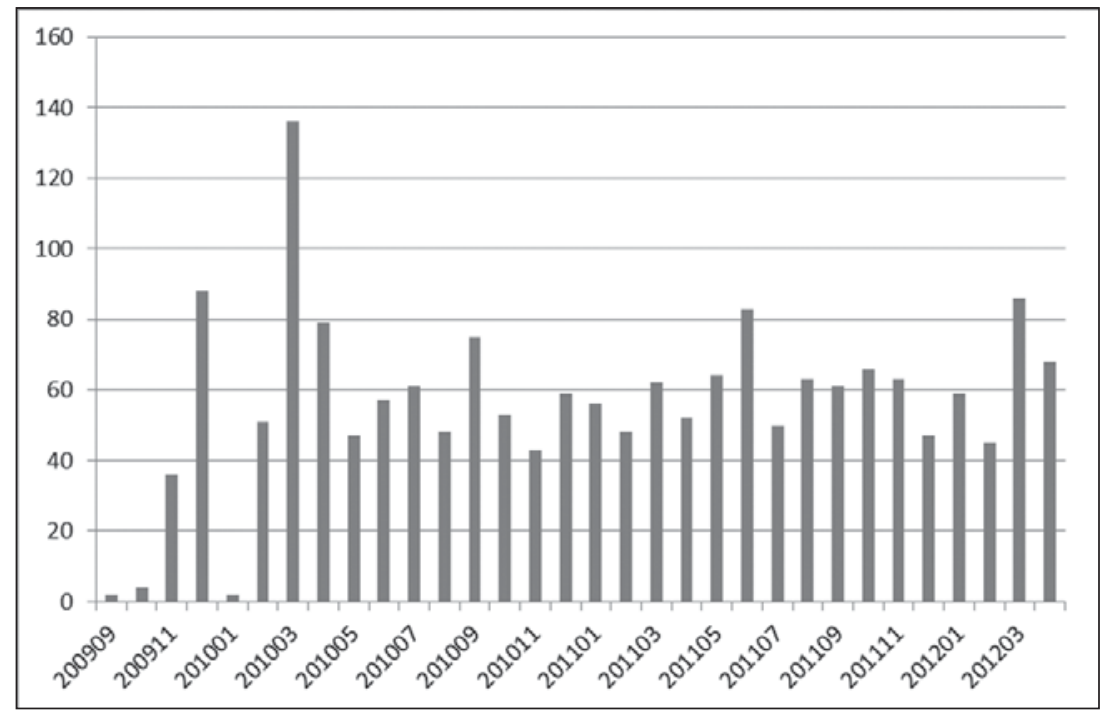

Rycina 3. Liczba nowych pacjentów włączanych do programu leczenia raka nerki w okresie od września 2009 r. do kwietnia 2014 r. Źródło: Centrala NFZ

kluczono niekontrolowane choroby układu sercowo-naczyniowego [10].

W drugiej linii leczenia, po niepowodzeniu leczenia inhibitorami kinazy tyrozynowej, program umożliwia zastosowanie ewerolimusu oraz - po niepowodzeniu immunoterapii interferonem alfa - sorafenibu. Program nie obejmuje bewacyzumabu, pazopanibu i temsyrolimusu z powodu braku pozytywnej rekomendacji Prezesa AOTM dla wymienionych leków. Obecnie w przypadku chorych z grupy niekorzystnego rokowania według skali MSKCC koszyk świadczeń gwarantowanych nie zawiera możliwości leczenia zgodnej z klinicznymi zaleceniami.

Systematyczny wzrost liczby chorych leczonych w programie od września 2009 r. przedstawia rycina 2. W związku z objęciem od początku 2012 r. nowych substancji czynnych (sorafenib i ewerolimus) należy się spodziewać dalszego wzrostu liczby pacjentów leczonych w ramach programu.

W zakresie tempa włączania nowych chorych do programu dane NFZ wskazują na regularne fluktuacje, które są najprawdopodobniej związane z podpisywaniem umów oraz zmianami wysokości kontraktów wynikającymi z negocjacji i rokowań (ryc. 3).

\section{Nakłady Narodowego Funduszu Zdrowia na leczenie chorych na raka nerkowokomórkowego i koszty Zakładu Ubezpieczeń Społecznych}

W ciągu ostatnich kilku lat do leczenia chorych z rozpoznaniem zaawansowanego RNK zarejestrowanych zostało w Europie kilka leków o działaniu ukierunkowanym molekularnie, które poprawiły rokowanie chorych. Należą do nich: 
Tabela II. Wartość zgód na chemioterapię niestandardową we wskazaniu rak nerki (C-64) w okresie od stycznia 2008 r. do kwietnia 2012 r.

\begin{tabular}{lcccc}
\hline Nazwa międzynarodowa & $\begin{array}{c}2008 \\
\text { Wartość zgód }\end{array}$ & $\begin{array}{c}2009 \\
\text { Wartość zgód }\end{array}$ & $\begin{array}{c}2010 \\
\text { Wartość zgód }\end{array}$ & $\begin{array}{c}2011 \\
\text { Wartość zgód }\end{array}$ \\
\hline temsyrolimus & & 4707174 & 1659583 & 376533 \\
Wewacyzumab & 246120 & 6786284 & 3695612 & 1857201 \\
ewerolimus & & 485662 & 19897503 & 24029157 \\
pazopanib & & & 2263390 & 8771019 \\
sorafenib & 527949 & 15822714 & 7815797 & 4637165 \\
sunitynib & 1043205 & 25534510 & 5992784 & 2437467 \\
\hline
\end{tabular}

Źródło: Centrala NFZ

- leki o działaniu antyangiogennym:

a) drobnocząsteczkowe inhibitory kinaz tyrozynowych receptora dla czynnika wzrostu śródbłonka naczyniowego (vascular endothelial growth factor receptor-tyrosine kinase inhibitors - VEGFR-TKI) — sunitynib, sorafenib, pazopanib,

b) przeciwciało monoklonalne anty-VEGF — bewacyzumab,

- inhibitory kinazy serynowo-treoninowej mTOR — temsyrolimus, ewerolimus.

Zgodnie z obowiązującymi do końca 2011 roku przepisami wszystkie nowe metody leczenia od chwili dopuszczenia do obrotu mogły być finansowane przez NFZ w ramach zgody indywidualnej udzielanej przez dyrektorów oddziałów wojewódzkich NFZ (chemioterapia niestandardowa). W przypadku kolejnych nowych leków, zarejestrowanych po 31 grudnia 2011 r. - według art. 70 ustawy z dnia 12 maja 2011 r. o refundacji leków, środków spożywczych specjalnego przeznaczenia żywieniowego oraz wyrobów medycznych - nie mogą one być już finansowane w ramach chemioterapii niestandardowej. W praktyce, aby zostały objęte refundacją, muszą uzyskać wcześniej pozytywną rekomendację Prezesa AOTM oraz pozytywne stanowisko Komisji Ekonomicznej (oba podmioty pełnią jedynie funkcję doradczą i ich opinie formalnie nie mają charakteru wiążącego względem Ministra Zdrowia).

W programie leczenia RNK - wprowadzonym przez NFZ w 2009 roku — finansowany był pierwotnie wyłącznie sunitynib. Od lutego 2012 roku do systemowego finansowania w ramach programu lekowego włączone zostały również leki drugiej linii (sorafenib i ewerolimus). Pozostałe leki do czasu otrzymania pozytywnej rekomendacji Prezesa AOTM i stanowiska Komisji Ekonomicznej nie będą objęte programem. Należy jednocześnie podkreślić, iż aktualnie liczna grupa chorych kontynuuje włączone przed styczniem 2012 r. leczenie ewerolimusem lub sorafenibem w ramach chemioterapii niestandardowej w związku z niespełnieniem kryteriów włączenia określonych w opisie programu dla wymienionych leków (prawa nabyte chorego).

Zgodnie z danymi NFZ, dotyczącymi chemioterapii niestandardowej, w okresie od stycznia 2008 r. do kwietnia 2012 r. największe wydatki poniesione zostały przez płat- nika na finansowanie leczenia ewerolimusem, sunitynibem i sorafenibem (tab. II).

W ujęciu kompleksowym wydatki płatnika na wszystkie świadczenia zdrowotne, w ramach których sprawozdano RNK jako rozpoznanie główne, przedstawiono na rycinie 4. Niezwykle istotny jest fakt, że wydatki na leczenie tego nowotworu z każdym rokiem systematycznie rosną, osiągając w 2011 roku poziom około 160 milionów złotych. Równocześnie rośnie wielkość populacji chorych z tym rozpoznaniem, która wg danych NFZ w 2011 r. przekroczyła 32 tysięcy chorych (unikalne numery PESEL). Wartość jest jednak zawyżona w związku z przypadkami sprawozdawania kodu C-64 w przypadku podejrzenia RNK, które następnie nie zostało potwierdzone histopatologicznie.

Jedną z przyczyn wzrostu nakładów ponoszonych przez płatnika na leczenia RNK jest znaczne poszerzenie możliwości wykrywania i leczenia w ostatnich latach, który nadal jest często rozpoznawany w stadium zaawansowania miejscowego lub uogólnienia (odpowiednio - po około $25 \%$ chorych). Ponadto sekwencyjne stosowanie leków skutkuje wydłużeniem procesu terapeutycznego, powoduje uzupełnienie - nie zastępowanie - poprzednio stosowanych metod leczenia przez kolejne i wzrost kosztów w systemie finansowania świadczeń zdrowotnych.

Niestety, nowe leki umożliwiają uzyskanie obiektywnych korzyści jedynie u części chorych, co wynika ze złożonej charakterystyki biologicznej RNK, braku wiarygodnych czynników predykcyjnych oraz występowania oporności o nieznanych mechanizmach. Rosnące koszty leczenia chorych na RNK uzasadniają konieczność prowadzenia badań nad precyzyjną identyfikacją populacji chorych, którzy odnoszą największe korzyści z określonego leczenia ukierunkowanego molekularnie.

W tabeli IV przedstawiono kompleksowe dane dotyczące wydatków NFZ na wszystkie świadczenia (szpitalne i ambulatoryjne) udzielone świadczeniobiorcom w związku z leczeniem chorych na RNK. We wszystkich województwach obserwujemy systematyczny wzrost wydatków na przedmiotowe świadczenia. Jednak należy zauważyć, że ważnym czynnikiem przyczyniającym się do znaczącego wzrostu wydatków w 2009 roku było podniesienie wartości 
Tabela III. Wartość wydatków NFZ poniesionych na finansowanie substancji czynnych w ramach programu leczenia raka nerki w okresie od października 2009 r. do marca 2012 r.

\begin{tabular}{lccc}
\hline Rok & Nazwa międzynarodowa & Liczba pacjentów leczonych & Wartość wykonanych świadczeń \\
\hline 2009 & sunitynib & 128 & 1975125 \\
2010 & sunitynib & 790 & 33943854 \\
2011 & sunitynib & 1117 & 59471740 \\
2012 & ewerolimus & 120 & 3180071 \\
2012 & sorafenib & 33 & 593174 \\
2012 & sunitynib & 774 & 20290118 \\
\hline
\end{tabular}

Źródło: Centrala NFZ

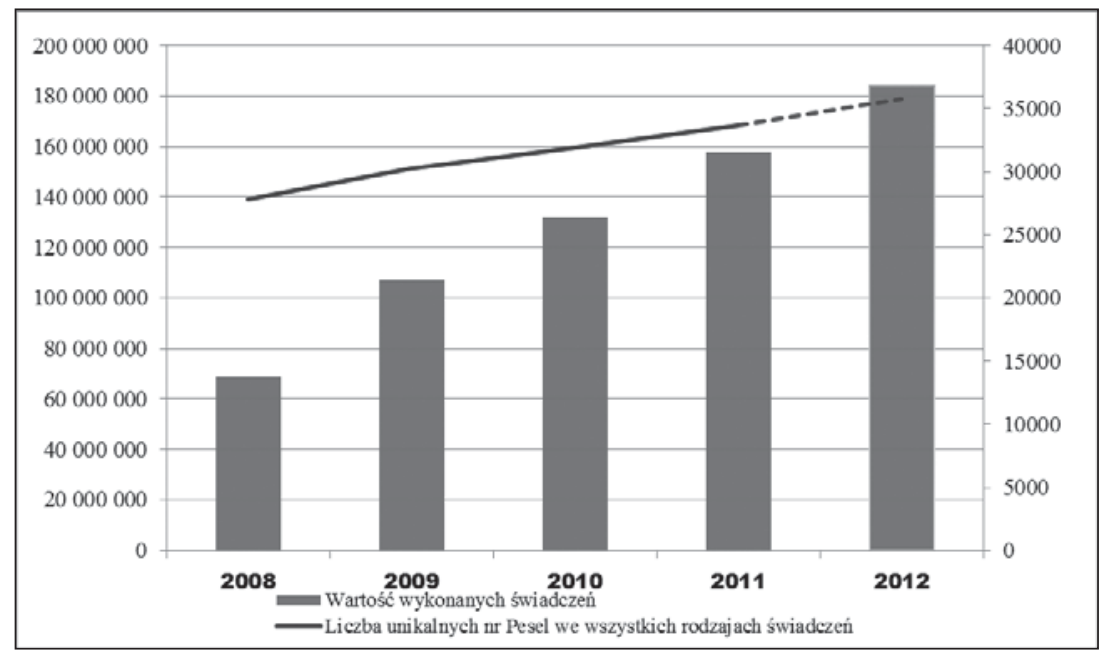

Rycina 4. Wartości wykonanych świadczeń zdrowotnych (szpitalnych i ambulatoryjnych) oraz liczba pacjentów, dla których sprawozdano raka nerki (C-64) jako rozpoznanie główne w latach 2008-2012 (wyniki za 2012 rok ekstrapolowano na podstawie danych sprawozdanych do kwietnia 2012 roku). Źródło: Centrala NFZ

Tabela IV. Wartości wykonanych świadczeń (szpitalnych i ambulatoryjnych), dla których sprawozdano raka nerkowokomórkowego jako rozpoznanie główne, w okresie od początku 2008 r. do kwietnia 2012 r. w podziale na oddziały wojewódzkie NFZ

\begin{tabular}{|c|c|c|c|c|c|}
\hline OW NFZ & 2008 & 2009 & 2010 & 2011 & 2012 \\
\hline dolnośląski & 3898569,76 & 4885033,10 & 5456105,71 & 7293005,58 & 2734412,13 \\
\hline kujawsko-pomorski & 5297151,95 & 8379440,49 & 8000464,82 & 8609402,46 & 3398308,78 \\
\hline lubelski & 4460532,95 & 4049717,08 & 5123890,77 & 7488971,04 & 2880352,09 \\
\hline lubuski & 1370224,21 & 2689115,01 & 3037064,18 & 3203280,18 & 854368,42 \\
\hline łódzki & 4829949,72 & 7451279,29 & 9270764,37 & 10583957,13 & 2726210,59 \\
\hline małopolski & 3975511,56 & 6482697,09 & 6963648,49 & 9071841,90 & 2497555,74 \\
\hline mazowiecki & 13566863,21 & 24660745,83 & 31575589,53 & 37636793,31 & 11380148,20 \\
\hline opolski & 1897195,06 & 2714717,47 & 2867860,23 & 2681797,51 & 459598,42 \\
\hline podkarpacki & 2282167,12 & 3031810,47 & 4823747,89 & 7146298,09 & 2968058,62 \\
\hline podlaski & 3530391,71 & 4870701,95 & 4733989,73 & 5422605,87 & 1751036,50 \\
\hline pomorski & 3042633,16 & 4614862,95 & 6441760,22 & 6633490,16 & 2424 107,92 \\
\hline śląski & 9066530,39 & 11186375,82 & 18042678,40 & 22004185,35 & 4528273,71 \\
\hline świętokrzyski & 1721156,79 & 4805580,60 & 6307815,65 & 6688619,11 & 2350492,22 \\
\hline warmińsko-mazurski & 1830409,89 & 2048173,53 & 2406449,78 & 2710136,15 & 663750,57 \\
\hline wielkopolski & 5221735,19 & 9572274,37 & 11358664,72 & 13844395,57 & 3977091,91 \\
\hline zachodniopomorski & 2591523,12 & 5873976,05 & 5667217,84 & 6965924,41 & 1793263,69 \\
\hline
\end{tabular}

Źródło: Centrala NFZ 
punktowej osobodnia i porady ambulatoryjnej związanej z chemioterapią w 2009 roku. Ponadto w roku 2009 wprowadzono nowy system rozliczeń dla świadczeń szpitalnych (JGP), co również sprzyjało realizacji kontraktów szpitalnych w zakresie onkologii, chirurgii onkologicznej i urologii. Wreszcie rosnąca z każdym rokiem liczba leków ukierunkowanych molekularnie skutkowała wzrostem nakładów NFZ na chemioterapię niestandardową.

Analizując kompleksowo koszty związane z RNK, należy również uwzględnić koszty pośrednie, wśród których największą część stanowią koszty związane z niezdolnością do pracy spowodowaną RNK. Jak wskazują dane udostępnione przez Zakład Ubezpieczeń Społecznych (ZUS), roczne koszty ponoszone z tego tytułu (ICD-10, C64) wynoszą około $42,9 \mathrm{mln}$ zł [11].

Powyższa kwota obejmuje:

- wydatki na renty z tytułu niezdolności do pracy łącznie z dodatkami pielęgnacyjnymi przysługującymi z tytułu tej niezdolności, ponoszone ze środków Funduszu Ubezpieczeń Społecznych (FUS);

- wydatki na renty socjalne, pokrywane ze środków budżetu państwa;

- wydatki na absencję chorobową, czyli czasową niezdolność do pracy z tytułu choroby własnej oraz zasiłki chorobowe wypłacane przez ZUS ze środków FUS;

- wydatki na świadczenia rehabilitacyjne z FUS;

- wydatki na rehabilitację leczniczą w ramach prewencji rentowej ZUS, pokrywane z FUS.

W świetle wydatków NFZ koszty ponoszone z tytułu RNK przez ZUS mogą wydawać się niewysokie, jednak ich wartość determinowana jest w głównej mierze późnym rozpoznawaniem tego nowotworu i relatywnie krótkim przeżyciem w stadium uogólnionym.

\section{Podsumowanie}

Mimo iż przedstawione dane dotyczące średniego przeżycia całkowitego chorych z rozpoznaniem RNK dla większości leków ukierunkowanych molekularnie na chwilę obecną nie mogą stanowić podstawy do ostatecznego wnioskowania odnośnie efektywności wspomnianych metod leczenia w warunkach rzeczywistych, to w dłuższym horyzoncie czasowym mogą one stanowić cenne źródło informacji wykorzystywanych w procesie optymalizacji programów lekowych.

Wciąż trwające poszukiwania molekularnych czynników predykcyjnych pozwalających na precyzyjniejszy dobór chorych do poszczególnych sposobów leczenia stwarzają potrzebę dokładnej oceny czynników klinicznych (np. stan sprawności ogólnej, wiek, typ histologiczny nowotworu, kategoria rokownicza według MSKCC, wykonanie nefrektomii, miejsce występowania przerzutów oraz współwystępujące choroby). Narzędziem wspierającym monitorowanie i analizę kluczowych czynników klinicznych oraz wyników terapii ukierunkowanych molekularnie mógłby być centralny rejestr chorych na RNK, nadzorowany przez zespół koordynujący. Uzyskane dzięki niemu nowe informacje odnośnie wskaźników przeżycia mogłyby okazać się użyteczne w rozwoju leczenia sekwencyjnego w przyszłości. Ponadto precyzyjne monitorowanie w centralnym rejestrze danych dotyczących mediany PFS i OS umożliwiłoby Ministrowi Zdrowia wdrożenie nowych mechanizmów refundacyjnych stosowanych w innych krajach (np. coverage with evidence development), poprawiających dostępność nowych i wysokokosztowych terapii. Mając na uwadze rosnącą ilość nowych leków rejestrowanych na podstawie badań z wykorzystaniem metody cross-over, wydaje się, iż rola tego typu mechanizmów w przyszłości będzie rosła.

Zgodnie z danymi NFZ liczba chorych na RNK otrzymujących leki ukierunkowane molekularnie będzie w najbliższych latach rosła, co będzie spowodowane zarówno zmianami struktury wieku społeczeństwa (szczególnie wskutek wyraźnego wzrostu liczby osób w wieku poprodukcyjnym) oraz poprawą diagnostyki i dalszym rozwojem nowych terapii ukierunkowanych molekularnie. Towarzyszyć temu będzie wzrost wydatków NFZ, jakkolwiek w znacznym stopniu może on zostać skompensowany przez wprowadzone ustawą instrumenty dzielenia ryzyka [12]. Dodatkowym czynnikiem, mającym wpływ na poszerzanie koszyka świadczeń gwarantowanych o kolejne leki ukierunkowane molekularnie stosowane w RNK będzie rozwój możliwości precyzyjnego kwalifikowania chorych do określonych metod leczenia. Korzystny wpływ na postęp wiedzy w tym zakresie mogą paradoksalnie mieć ograniczenia finansowania wynikające z analiz farmakoekonomicznych przeprowadzanych dziś w wielu krajach, wskazujących na niską efektywność kosztową terapii teoretycznie „celowanych", jednak w sytuacji braku molekularnych czynników predykcyjnych stosowanych de facto - empirycznie. Od tego postępu zależeć będzie w najbliższej, trudnej ekonomicznie przyszłości, ilu chorych z rozpoznaniem RNK skorzysta z nowych, skuteczniejszych i lepiej tolerowanych metod leczenia, ocenianych dziś w próbach klinicznych.

\section{Lek. Rafał Zyśk}

Kancelaria Doradcza

Health Economics Consulting

ul. Słomińskiego 19/132,00-154 Warszawa

e-mail: rafal.zysk@hec.pl

Otrzymano: 19 września $2012 \mathrm{r}$.

Przyjęto do druku: 30 października 2012 r.

\section{Piśmiennictwo}

1. Bray F, Jemal A, Grey Ni wsp. Global cancer transitions according to the Human Development Index (2008-2030): a population-based study. Lancet Oncol 2012: 13: 790-801.

2. Podstawowe informacje o sytuacji demograficznej Polski w 2011 roku. Warszawa: GUS, 2012.

3. Siegel R, Naishadham D, Jemal A. Cancer statistics, 2012. CA Cancer J Clin 2012; 62: 10-29. 
4. Didkowska J, Wojciechowska U, Zatoński W. Nowotwory złośliwe w Polsce w 2009 roku. Centrum Onkologii — Instytut im. Marii Skłodowskiej-Curie, Warszawa 2011.

5. Didkowska J, Wojciechowska U, Zatoński W. Prognozy zachorowalności i umieralności na nowotwory złośliwe w Polsce do 2025 r. Krajowy Rejestr Nowotworów. Warszawa 2009.

6. Prognoza ludności na lata 2008-2035. GUS Departament Badań Demograficznych. Warszawa 2009.

7. Zalecenia postępowania diagnostyczno-terapeutycznego Polskiej Unii Onkologii. Gdańsk 2011.
8. Measuring survival time: probability-based approach useful in healthcare decision making. Prescrire International, July-August 2011/Volume 20, No 118

9. http://www.who.int/classifications/icd/adaptations/oncology/en/.

10. Obwieszczenie Ministra Zdrowia z dnia 28 czerwca 2012. Załącznik B.10 - Leczenie raka nerki (ICD-10 C 64).

11. Koszty ZUS poniesione na świadczenia z tytułu niezdolności do pracy spowodowanej rakiem nerki w roku 2010. www.zus.pl.

12. Ustawa z dnia 12 maja 2011 r. o refundacji leków, środków spożywczych specjalnego przeznaczenia żywieniowego oraz wyrobów medycznych. 